\title{
DESIGN OF AN EFFICIENT MICROGRID SYSTEM FOR A LOCAL AREA
}

\author{
P. D. Singh \\ Assistant Professor, Department of Electrical Engineering, \\ North Eastern Regional Institute of Science and Technology, Nirjuli, India \\ Ajay Upadhaya, Michael Simte, Heisnam Jimbrown Singh \\ Department of Electrical Engineering, North Eastern Regional Institute of Science and \\ Technology, Nirjuli, India
}

\begin{abstract}
Microgrid (MG) system has a vital role in fulfilling the ever increasing electricity demand in the continuously expanding power systems. Significant power can be integrated from Renewable energy sources such as solar, wind and small hydro to $M G$ systems. MG may a distribution power network of either low voltage level or medium voltage level consisting of various energy sources from distributed generations (DG's) such as photovoltaic system, fuel cell, biomass, wind, small hydro, energy storage systems, etc. $M G$ can be a single controllable system which can be operated in islanded mode without connecting to main grid or grid-connected mode. This study presents the design of MG system based on a given load data and available resources for minimum cost of energy, maintenance and replacement. The design is carried out using HOMER Software so as to maximize the energy usage from the DG's instead of grid supply to meet most of the load demand in the MG system. The study presents an approach to an efficient $M G$ system design based on available renewable power generation units for the most efficient distributed energy sources and optimum ratings of the components required to meet the load demand of a known local area. It also presents the techno-economic feasibility study of the MG system so designed. The simulation results and discussions are presented.
\end{abstract}

Keywords: Microgrid System, Battery Energy Storage, Distributed Generation, Grid Connected and Islanded Microgrid System, HOMER, Solar PV

Cite this Article: P. D. Singh, Ajay Upadhaya, Michael Simte, Heisnam Jimbrown Singh, Design of an Efficient Microgrid System for a Local Area, International Journal of Electrical Engineering \& Technology, 10(3), 2019, pp. 64-72.

http://iaeme.com/Home/issue/IJEET?Volume=10\&Issue $=3$

\section{INTRODUCTION}

The conventional electricity generation from fossil fuels contributes in degradation of the environment. Moreover, the demand of electricity is increasing day by day necessitating to 
inject more of renewable energy which is available in the form of distributed energy. Distributed energy sources such as PV, Wind, Tidal, Micro Hydro, Fuel cells etc. in conjunction with these conventional sources can supplement the increasing demand. These Distributed Energy Resources (DER) can alone form a small grid called Microgrid to supply a particular area while feeding the excess generation to the main grid [9]. MG can therefore operate in island mode or grid connected mode. In island mode, the MG is sufficient to meet the local load demand and it does not supply electricity to the grid nor take it from the grid. In grid connected mode, the MG takes from the grid during shortage of power generation and supply to grid during when the power generation exceeds the required load demand. In a microgrid, the power generation as well as the load are constantly changing. MGs are formed by a number of Distributed Generations which do not provide constant power generation [8]. The DERs need to be properly interfaced with power electronic devices for controlling the flexibility of operation with improved power quality and energy output [10]. HOMER software is a popular computer tool which can perform simulation and optimisation of standalone and grid-connected electric power systems having various DERs [1, 6]. HOMER software has been used in many studies for assessments of potential of wind energy [2], winddiesel system [3], zero-energy homes [4], stand-alone system having hydrogen [5]. HOMER has also presented simulation study of a system having 100\% load demand met by renewable energy sources [6]. This paper presents design of MG system consisting of PV array system, a MPPT with boost converter for PV array, a battery with bidirectional charge controller, a three-phase inverter to convert $\mathrm{DC}$ to $\mathrm{AC}$ power, transformer for $\mathrm{AC}$ voltage conversion, load and a grid. A maximum power point tracking (MPPT) controller is required to extract the maximum power in the PV through the boost converter. A storage unit like battery helps to maintain stability during transient and varying load conditions. A charge controller is used for controlling the battery to charge and discharge during excess and shortage of power respectively [7]. The techno-economic feasibility analysis of the MG system is carried out using HOMER. The simulation results and analysis are presented and discussed in the subsequent chapters.

\section{MG SYSTEM DESIGN USING HOMER SOFTWARE}

In this work, Homer Pro is used as it provides the some readily available data of location such as Sunshine, Wind Speed, Rainfall, Temperature, etc. Moreover, it provides the option to used real time components as well as user defined components. Resources like daily, monthly, yearly data of temperature, Wind Resource, Solar Radiation, etc. are directly obtained from NASA server. Approximate maximum size of components and pattern of resources are suitably defined based on the local load area considered. For the study, the load assessment is carried out for the local area under consideration followed by system designing as follows.

\subsection{Electric Load Profile}

The energy consumed by the locality under study is found to be $537 \mathrm{kWh} /$ day with peak demand of $55.24 \mathrm{~kW}$ and load factor of 0.41 . The random variability from day to day and time step are assumed to be 5\%. The load profiles for the specified system can be shown by HOMER in Figures 1 (a) and (b). The load is at its peak from $7 \mathrm{pm}$ to $8 \mathrm{pm}$ and minimum between 12 am to $3 \mathrm{am}$. 


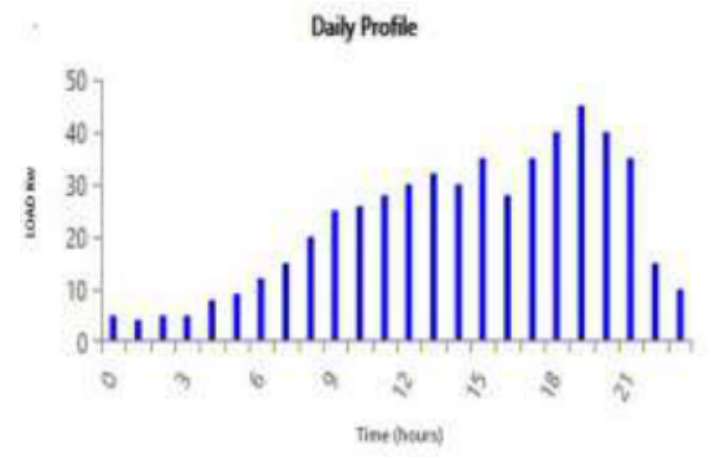

(a)

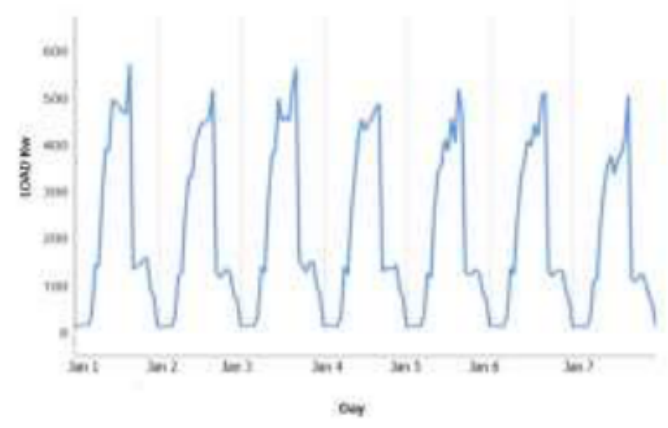

(b)

Figure 1 (a) Daily Load Profile of the Area (b) Daily Load Profile with 5\% Variability

\subsection{Design Considerations}

Based on the load assessments, the MG design considers a system including a Generic PV, $1 \mathrm{kWh}$ Li-Ion Storage Batteries, Converter, Load and Grid as shown in Fig. 2. The complete system descriptions viz. Solar resource, Temperature resource and detail of the various components are discussed in the following sub-headings.

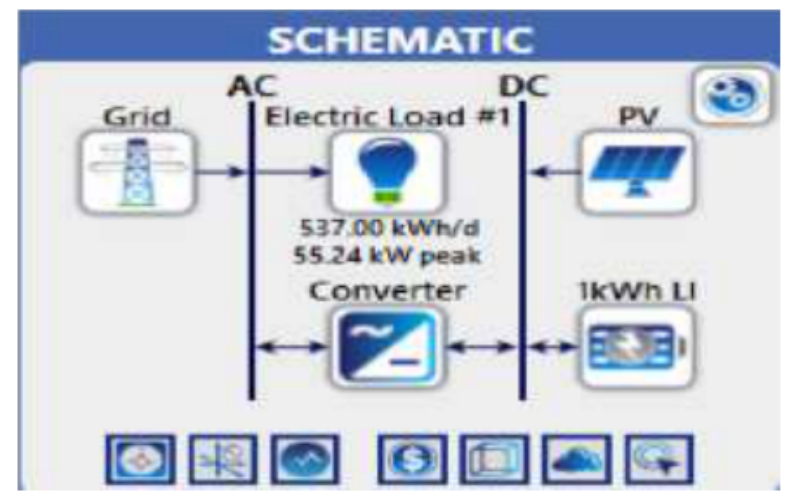

Figure 2 Schematic Diagram of Microgrid System Design

\subsection{System Description}

\subsubsection{Solar Resources}

The solar data for the location was loaded from the Hybrid Optimization Model for Electric Renewables (HOMER) database by specifying the locations coordinates of $27.1^{\circ} \mathrm{N} 93.62^{\circ} \mathrm{E}$. It has a relatively strong solar resource with a daily radiation annual average of 3.95 $\mathrm{Kwh} / \mathrm{m}^{2} /$ day. A graph of the global horizontal radiation is shown in Fig. 3. The months from April to June have the highest values of solar radiation.

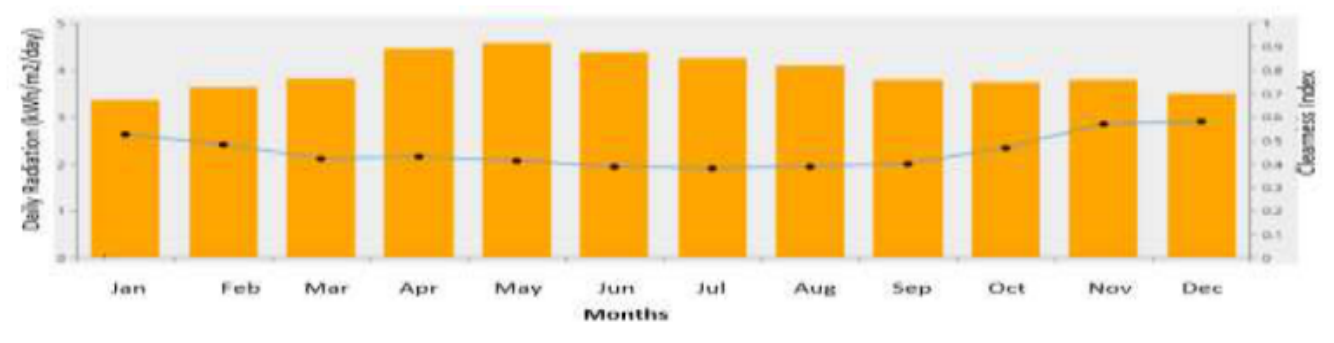

Figure 3 Monthly Average Radiation 


\subsubsection{Temperature Resource}

The daily temperature of the selected location throughout the year is shown Fig. 4. The annual average temperature was found to be $23.89^{\circ} \mathrm{C}$. The temperature is highest during May and June followed by April, July and August.

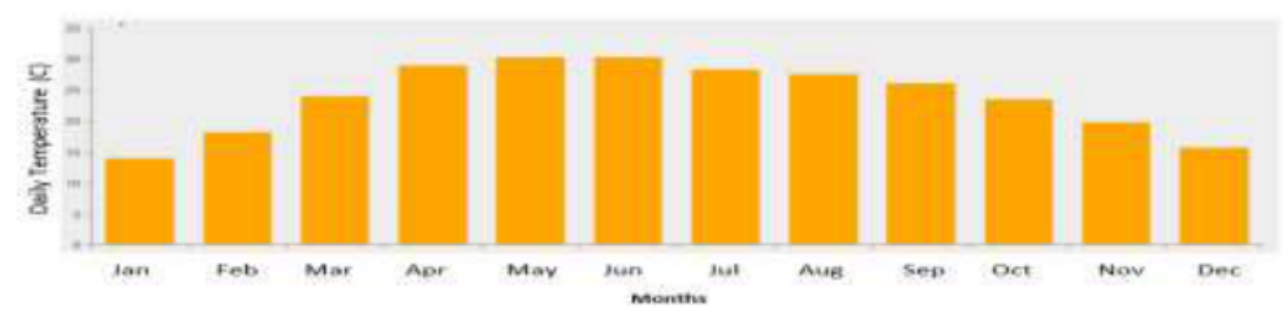

Figure 4 Monthly Average Temperature

\subsubsection{PV Module}

Solar PV modules are arranged in series-parallel connection. PV Array is the main source of generation. In this hybrid design, a Generic $1 \mathrm{~kW}$ flat is considered. The capital cost and replacement cost are taken as $\$ 600$ and $\$ 550$ respectively. The maintenance cost is assumed to be $\$ 5 / y r$. De-rating factor of $90 \%$ is considered. The sizing for simulation is taken by Homer Optimizer.

\subsubsection{Battery}

A battery bank not only provides the backup power but also helps in maintaining constant voltage across the load. Its capacity should be sufficient enough to store energy for operating the load during cloudy days and night times. The capital and replacement costs are taken to be $\$ 300 / \mathrm{kW}$. Some specifications of the battery are given in Table 1 and detail specifications is given in the Appendix.

Table 1 Specifications of Battery

\begin{tabular}{|l|l|}
\hline Nominal Voltage & $24 \mathrm{~V}$ \\
\hline Nominal Capacity & $167 \mathrm{Ah} / 1 \mathrm{kWh}$ \\
\hline Roundtrip Efficiency & $90 \%$ \\
\hline
\end{tabular}

\subsubsection{Converter}

The converter used is bidirectional that converts electrical power from AC to DC or from DC to AC. In our simulation we have considered a generic system converter given in HOMER library. For a $1 \mathrm{~kW}$ system the installation, capital and replacement costs are taken as \$200 and $\$ 150$ respectively.

Table 2 Converter Efficiency and Life Expectancy

\begin{tabular}{|l|l|}
\hline Inverter Input & Rectifier Input \\
\hline Lifetime : 25 Years & Relative Capacity : 100\% \\
\hline Efficiency : 95\% & Efficiency : 95\% \\
\hline
\end{tabular}

\subsubsection{Controller}

For the required design, the simulation is carried out with controller Load Following dispatch (LF). In load following dispatch, the grid is used only when the DG is unable to produce sufficient power for load. 


\subsubsection{Grid}

The Microgrid is provided with an alternative to connect to the grid. When power generated is less than load demand, power may be taken from grid or else it injects power to the grid. The sale capacity to the grid is set to $34 \mathrm{~kW}$ and purchase capacity from the grid is $100 \mathrm{~kW} / \mathrm{month}$. Interconnection charges of $\$ 3000$ and standby charges of $\$ 500 / \mathrm{yr}$ are considered. The cost of grid extension is assumed to be $\$ 300 / \mathrm{km}$.

\section{SIMULATION AND RESULTS OF MG DESIGN BY HOMER SOFTWARE}

The complete model consisting of defined PV System, Battery, Converter, Load and Grid is simulated using Homer Optimizer. Sizing of components is done by Homer Optimizer. 861 solutions were simulated. 612 were feasible, 86 were omitted. HOMER provides different configurations of all the systems which are feasible under the defined search constraints. Then, they are arranged according to the minimum cost MG based on the total net present cost (NPC). By analysing the optimization result in categorized way, it can be said that among all the system configuration, the configuration of PV and Grid is found to be the most optimum one. Since the desired system is to minimize dependency on grid, the second configuration with battery is taken. The system NPC and COE of this configuration is lesser than that of the other configuration. The optimization result of the system is shown in Fig. 5.

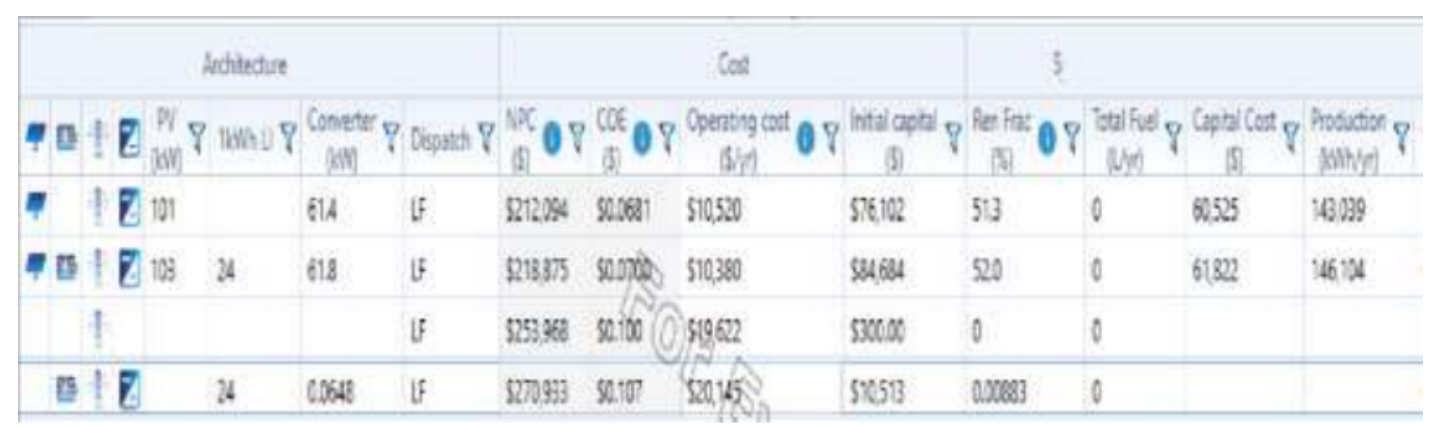

Figure 5 Optimization Result

For comparison of the optimized result two cases are considered.

Case 1: In this case, the second configuration with the most optimized result including grid, $\mathrm{PV}$, converter and battery is considered.

Case 2: In this case the third configuration from the optimization result is considered. In this configuration only the grid is considered.

In these two cases, it can be seen that the NPC and Levelized cost of energy (LCOE) of the Case 1 is lower than that of Case 2. The $\mathrm{CO}_{2}$ emission of Case 1 is also lower than that of the Case 2. Hence, the second configuration i.e. Case 1 is found to be the most optimum solution for feeding the load demand of the location. Capital Expenditure (CAPEX) and Operational Expenditure (OPEX) for Case 1 are also found lesser than that of Case 2 as shown in the table below.

Table 3 Comparison between Case 1 and Case 2

\begin{tabular}{|l|l|l|}
\hline Parameters & Case 1 & Case 2 \\
\hline Net Present Cost & $\$ 219,061$ & $\$ 253,968$ \\
\hline CAPEX & $\$ 83,590$ & $\$ 3000$ \\
\hline OPEX & $\$ 10,479$ & $\$ 19,622$ \\
\hline LCOE (per kWh) & $\$ 0.0704$ & $\$ 0.100$ \\
\hline CO2 Emitted (kg/year) & 73,631 & 123,816 \\
\hline Fuel Consumption (L/year) & 0 & 0 \\
\hline
\end{tabular}


The simulation results can be summarised as follows.

\subsection{Cost Summary}

The cost summary is shown in the table below. The project is designed for 25 years and the lifetime of all the components are assumed to be 25 years. Therefore, the replacement cost and salvage are found to be nil. The cost of the resource is also found to be nil since no fuel is used in the system as shown in Table 4.

Table 4 Net Present Costs

\begin{tabular}{|l|c|c|c|}
\hline \multicolumn{1}{|c|}{ Name } & Capital (in \$) & Operating (in \$) & Total (in \$) \\
\hline $\begin{array}{l}\text { Generic } \\
\text { 1kWh Li-Ion }\end{array}$ & 7,200 & 310.26 & 7,510 \\
\hline $\begin{array}{l}\text { Generic Flat } \\
\text { Plate PV }\end{array}$ & 60,603 & 6,529 & 67,132 \\
\hline Grid & 3,300 & 128,632 & 131,932 \\
\hline $\begin{array}{l}\text { System } \\
\text { Converter }\end{array}$ & 12,487 & 0.00 & 12,487 \\
\hline System & 83,590 & 135,471 & 219,061 \\
\hline
\end{tabular}

\subsection{Electrical Summary}

The simulation results below give the electrical energy exchange and capacity detail of all the components. Table 5 and 6 show the electricity produced, stored and supplied from the grid. Also, it is seen that there is no unit of energy demand left unmet.

Table 5 Energy Profile

\begin{tabular}{|l|l|c|}
\hline \multicolumn{1}{|c|}{ Quantity } & Value & \multicolumn{1}{c|}{ Units } \\
\hline Electricity in Excess & 11854 & $\mathrm{kWh} / \mathrm{yr}$ \\
\hline Demand left Unmet & 0 & $\mathrm{kWh} / \mathrm{yr}$ \\
\hline Capacity Shortage & 40.3 & $\mathrm{kWh} / \mathrm{yr}$ \\
\hline
\end{tabular}

Table 6 Production Scenario

\begin{tabular}{|l|l|l|}
\hline Component & Production & \% Units \\
\hline Generic Flat Plate PV & 143224 & 55.1 \\
\hline Grid Purchases & 116505 & 44.9 \\
\hline Total & 259729 & 100 \\
\hline
\end{tabular}

The statistics of PV module for the location considered are obtained as shown in Table 7. The simulation results give a rated capacity of $103 \mathrm{~kW}$ for supplementing the local load with a capacity factor of $16.2 \%$. The total energy production for this system is found to be 143,224 $\mathrm{kWh} / \mathrm{yr}$. The specifications of the battery system is given in Table 8 . The overall energy exchange detail of the battery system, system converter and grid are depicted in Tables 9, 10 and 11 respectively. 
P. D. Singh, Ajay Upadhaya, Michael Simte, Heisnam Jimbrown Singh

Table 7 PV System Statistics

\begin{tabular}{|l|l|l|}
\hline \multicolumn{1}{|c|}{ Quantity } & \multicolumn{1}{c|}{ Value } & \multicolumn{1}{c|}{ Units } \\
\hline Rated Plant Capacity & 103 & $\mathrm{~kW}$ \\
\hline Average Output & 16.3 & $\mathrm{~kW}$ \\
\hline Average Output/day & 392 & $\mathrm{kWh} /$ day \\
\hline Plant Factor & 16.2 & $\%$ \\
\hline Total Energy Production & 143,224 & $\mathrm{kWh} / \mathrm{yr}$ \\
\hline
\end{tabular}

Table 8 Generic 1kWh Li-on Battery Specifications

\begin{tabular}{|l|l|l|}
\hline \multicolumn{1}{|c|}{ Quantity } & \multicolumn{1}{c|}{ Value } & \multicolumn{1}{c|}{ Units } \\
\hline Batteries & 24 & Quantity in Number \\
\hline String Size & 4 & Number of Batteries \\
\hline Parallel Strings & 6 & Strings \\
\hline Bus Voltage & 24 & Volt \\
\hline
\end{tabular}

Table 9 Generic 1 kW Li-Ion Battery Result Data

\begin{tabular}{|l|l|l|}
\hline \multicolumn{1}{|c|}{ Quantity } & Value & \multicolumn{1}{c|}{ Units } \\
\hline Average Cost of Energy & 0 & $\$ / \mathrm{kWh}$ \\
\hline Energy Inflow & 7,239 & $\mathrm{kWh} / \mathrm{yr}$ \\
\hline Energy Outflow & 6,533 & $\mathrm{kWh} / \mathrm{yr}$ \\
\hline Battery Storage Depletion & 19.2 & $\mathrm{kWh} / \mathrm{yr}$ \\
\hline Energy Losses & 725 & $\mathrm{kWh} / \mathrm{yr}$ \\
\hline Annual Throughout & 6,887 & $\mathrm{kWh} / \mathrm{yr}$ \\
\hline
\end{tabular}

Table 10 System Converter Statistics

\begin{tabular}{|l|l|l|}
\hline \multicolumn{1}{|c|}{ Quantity } & \multicolumn{1}{c|}{ Value } & \multicolumn{1}{c|}{ Units } \\
\hline Operational Hours & 5,451 & $\mathrm{hrs} / \mathrm{yr}$ \\
\hline Energy Outflow & 124,131 & $\mathrm{kWh} / \mathrm{yr}$ \\
\hline Energy Inflow & 130,664 & $\mathrm{kWh} / \mathrm{yr}$ \\
\hline Energy Losses & 6,533 & $\mathrm{kWh} / \mathrm{yr}$ \\
\hline
\end{tabular}

Table 11 Grid Exchange Rate

\begin{tabular}{|c|l|l|l|l|l|l|}
\hline $\begin{array}{c}\text { Time } \\
\text { Period }\end{array}$ & $\begin{array}{l}\text { Energy } \\
\text { Received } \\
\mathbf{k W h})\end{array}$ & $\begin{array}{l}\text { Energy } \\
\text { Injected } \\
\mathbf{( k W h )}\end{array}$ & $\begin{array}{l}\text { Net } \\
\text { Energy } \\
\text { Received } \\
\mathbf{( k W h )}\end{array}$ & $\begin{array}{l}\text { Maximum } \\
\text { Demand } \\
\mathbf{( k W )}\end{array}$ & $\begin{array}{l}\text { Energy } \\
\text { Bill }\end{array}$ & $\begin{array}{l}\text { Demand } \\
\text { Bill }\end{array}$ \\
\hline Annual & 116,505 & 44,631 & 71,874 & 55.2 & $\$ 9,419$ & $\$ 31.25$ \\
\hline
\end{tabular}

\section{CONCLUSION}

Microgrid consisting of Solar PV, Battery System with Grid connection is employed to meet the load demand of a proposed residential area. HOMER Pro Software was employed for getting the optimized design of the Microgrid. The optimization result with integration of renewable energy resources are taken into consideration. Accordingly, the comparison between two configurations was presented and it was found that the system design consisting of $103 \mathrm{~kW}$ Solar PV, $24 \mathrm{kWh}$ capacity battery and $61.8 \mathrm{~kW}$ converter with grid connected system is found to be more feasible. The Net Present Cost (NPC) and Cost of Energy (COE) 
of the optimum design were found to be minimum compared to that of the other cases. The $\mathrm{CO}_{2}$ emission on the optimum design was found to be $73.631 \mathrm{~kg} / \mathrm{yr}$ which is lesser than that of the other cases. The Solar PV generation is $143224 \mathrm{kWh} / \mathrm{yr}$ which is $55.1 \%$ of the total power required and the remaining $49.9 \%$ i.e. $116505 \mathrm{kWh} / \mathrm{yr}$ is purchased from the grid. Hence, the system is dependent on main grid to some extent which could be improved by implementing other renewable resources in future. Thus, in all, this paper has presented an approach to design an efficient Microgrid system to meet the load demand of a proposed residential load and its analysis has shown that the system is feasible and optimum. Future studies may incorporate some more renewable energy resources like small hydro power plants, wind energy, biomass, fuel cells, etc. to further reduce the load shared by the main grid.

\section{REFERENCES}

[1] D. Connolly, H. Lund, B. V. Mathiesen, and M. Leahy, "A review of computer tools for analysing the integration of renewable energy into various energy systems," Appl. Energy, vol. 87, no. 4, pp. 1059-1082, 2010.

[2] G. Bekele and B. Palm, "Wind energy potential assessment at four typical locations in Ethiopia,” Appl. Energy, vol. 86, no. 3, pp. 388-396, 2009.

[3] S. Rehman et al., "Feasibility study of hybrid retrofits to an isolated off-grid diesel power plant," Renew. Sustain. Energy Rev., vol. 11, no. 4, pp. 635-653, 2007.

[4] M. T. Iqbal, "A feasibility study of a zero energy home in Newfoundland," Renew. Energy, vol. 29, no. 2, pp. 277-289, 2004.

[5] M. J. Khan and M. T. Iqbal, "Pre-feasibility study of stand-alone hybrid energy systems for applications in Newfoundland," Renew. Energy, vol. 30, no. 6, pp. 835-854, 2005.

[6] T. Lambert, P. Gilman, and P. Lilienthal, "Micropower System Modeling with Homer," in Integration of Alternative Sources of Energy, 2006, pp. 379-418.

[7] Fei Ding, Peng Li, Bibin Huang, Fei Gao, Chengdi Ding and Chengshan Wang, "Modeling and simulation of grid-connected hybrid photovoltaic/battery distributed generation system," CICED 2010 Proceedings, Nanjing, 2010, pp. 1-10.

[8] R.H.Lasseter, "Micro-grids", IEEE Power Engineering Society Winter Meeting, Vol.01, pp. 305- 308, New York, NY, 2015

[9] A. Banerji et al., "Microgrid: A review," 2013 IEEE Global Humanitarian Technology Conference: South Asia Satellite (GHTC-SAS), Trivandrum, 2013, pp. 27-35.

[10] Zhang and M. Huang, "Microgrid: A strategy to develop distributed renewable energy resource," in Proc. Int. Conf. Electrical and Control Engineering, Sep. 2011, pp. 35203523. 


\section{APPENDIX}

\section{PV System:}

Model: SunPower SPR-305E-WHT-D

PV type: Parallel String - 66, Series connected module per string - 5

Maximum Power - 305.226W

Cells Per Module - 96 N-Cell

\begin{tabular}{|l|c|c|}
\hline \multicolumn{1}{|c|}{ Module data } & V & I \\
\hline $\mathrm{V}_{\mathrm{oc}}, \mathrm{I}_{\mathrm{sc}}$ & $64.2 \mathrm{~V}$ & $5.96 \mathrm{~A}$ \\
\hline Max. power point & $54.7 \mathrm{~V}$ & $5.58 \mathrm{~A}$ \\
\hline Temperature Coefficient & $-0.27269 \% /$ deg.C & $0.061745 \% /$ deg.C \\
\hline
\end{tabular}

\section{Battery System:}

$\square \quad$ Type - Lead Acid, Nominal Voltage - 24V, Rated Capacity - 167Ah

$\square \quad$ Initial state-of-charge $-30 \%$, Battery response time -20 sec

$\square$ Maximum capacity $-104.1667 \mathrm{Ah}$, Cut-off voltage $-165 \mathrm{~V}$

$\square \quad$ Fully charge voltage $-500 \mathrm{~V}$, Nominal discharge current $-20 \mathrm{~A}$

$\square \quad$ Internal resistance $-0.022 \mathrm{Ohms}$, Capacity at nominal voltage $-31.0278 \mathrm{Ah}$ 